\title{
Protective effect of ambroxol against heat- and hydrogen peroxide- induced damage to lung lipids in mice
}

\author{
D. Nowak, A. Antczak, T. Pietras, P. Bialasiewicz, M. Krol
}

\begin{abstract}
Protective effect of ambroxol against heat- and hydrogen peroxide-induced damage to lung lipids in mice. D. Nowak, A. Antczak, T. Pietras, P. Bialasiewicz, M. Krol. CERS Journals Ltd 1994.

ABSTRACT: We wanted to determine whether ambroxol, a drug which stimulates the release of surfactant by type II pneumocytes, can protect lung lipids from peroxidative damage in mice.

Animals were injected intraperitoneally with ambroxol, $0.169 \mathrm{mmol} \cdot \mathrm{kg}^{-1}$, or $1 \mathrm{ml}$ buffer once a day for three consecutive days. Lipid peroxidation was then induced in lung homogenates either by means of heat, $50^{\circ} \mathrm{C}$, or $\mathrm{H}_{2} \mathrm{O}_{2}, 10 \mathrm{mmol} \cdot l^{-1}$.

The lung homogenates from ambroxol-treated animals revealed decreased lipid peroxidation in response to both stimuli. The heat- and $\mathrm{H}_{2} \mathrm{O}_{2}$-induced generation of conjugated dienes (a first lipid peroxidation product) in ambroxol-treated lung homogenates was 3.7 and 3.1 fold lower than in the lungs from buffer-injected mice. Ambroxol, as an inhibitor of heat- and $\mathrm{H}_{2} \mathrm{O}_{2}$-induced lipid peroxidation, was equipotent to and stronger than the two antioxidants, $\mathrm{N}$-acetylcysteine and methionine, respectively. Ambroxol was not able to protect heart and liver lipids.

These results suggest that ambroxol can sufficiently enhance the antioxidant defence in lung tissue and can act as a lung lipid antioxidant.
\end{abstract}

Eur Respir J., 1994, 7, 1629-1634.
Dept of Pneumology and Allergology, Medical University of Lodz, Lodz, Poland.

Correspondence: D. Nowak

Dept of Pneumology and Allergology

Medical University of Lodz

Kopcinskiego st 22

90-153 Lodz

Poland

Keywords: Ambroxol

conjugated dienes

lipid peroxidative damage

lung lipid peroxidation

lung lipids

Received: November 101993

Accepted after revision May 281994

This work was partly supported by Boehringer Ingelheim Pharma Ges mbH.
Reactive oxygen species and free radical lipid peroxidation may initiate pathological changes leading to the development of lung diseases, such as pulmonary emphysema, adult respiratory distress syndrome and lung cancer $[1,2]$. One possible method of preventing these diseases is the pharmacological enhancement of pulmonary antioxidant defence or suppression of free radical generation in lung tissue. The drug useful for this purpose should sufficiently scavenge reactive oxygen species and/or inhibit influx of activated phagocytes, which are the main source of reactive oxygen species in the respiratory tract.

Many studies have indicated that ambroxol (2-Amino3,5-dibromo-N-[trans-4-hydroxycyclohexyl] benzylamine), a drug from the expectorant class which stimulates the formation and release of surfactant by type II pneumocytes [3], may be a putative inhibitor of free radical-mediated processes in lung tissue [4]. Ambroxol was found to protect $\alpha_{1}$-proteinase inhibitor from oxidative inactivation [5], and to inhibit the chemotactic response and spontaneous migration of human polymorphonuclear leucocytes (PMNLs) $[6,7]$. Ambroxol also attenuated the zymosaninduced chemiluminescence of human PMNLs and alveolar macrophages [8], and inhibited interleukin-1 and tumour necrosis factor production by human mononuclear cells stimulated with lipopolysaccharide [9]. This drug diminished the bleomycin-induced lung injury in rats [10], and decreased their mortality after administration of paraquat, a herbicide which generates reactive oxygen species [11]. Recently, we found that intraperitoneal administration of ambroxol protected lung and heart lipids from oxidative stress provoked by intravenous injection of endotoxin in mice [12]. In this animal model, ambroxol was found to be equipotent to $\mathrm{N}$-acetylcysteine, a wellknown antioxidant [13], in inhibition of lipid peroxidation [14]. Moreover, this drug was also able to scavenge hypochlorous acid and hydroxyl radicals $(\mathrm{OH} \cdot)$, and to inhibit lipid peroxidation in vitro. At concentrations of 1-5 mM, it completely inhibited generation of malondialdehyde from linoleic acid incubated with an $\mathrm{OH} \cdot-$ generating system $\left(\mathrm{Fe}^{2+} 10 \mu \mathrm{m}, \mathrm{H}_{2} \mathrm{O}_{2} 280 \mu \mathrm{M}\right.$, ethylene diamine tetra-acetic acid (EDTA) $20 \mu \mathrm{M}$ ) [15].

Taking the above into consideration, it seems that ambroxol may protect lung tissue, especially lung lipids, from peroxidative damage. Unfortunately, there is no basic information yet available on its capacity to act as lipid antioxidant in vivo. Therefore, the aim of the present study was to explore whether intraperitoneal administration of ambroxol changes the susceptibility of lung lipids to peroxidative damage. By measurement of conjugated dienes (CD), a first lipid peroxidation product, we have found that lung homogenates from ambroxol-treated animals revealed decreased lipid peroxidation in response to thermal and chemical stimuli. The protective effect of ambroxol on lung lipids was stronger than that caused by the two antioxidants, $\mathrm{N}$-acetylcysteine and methionine. 


\section{Material and methods}

\section{Reagents}

Ambroxol hydrochloride was a kind gift from $\mathrm{W}$. Trautner (Boehringer Ingelheim, Vienna). N-acetylcysteine was from the Zambon Group (Switzerland). Methionine was obtained from Serva Feinbiochemica (Heidelberg). Chloroform (for spectroscopy), and heptane were from Ubichem (UK). All other reagents were purchased from $\mathrm{POCH}$ (Poland). Ambroxol, N-acetylcysteine and methionine were dissolved in $0.2 \mathrm{~mol} \cdot l^{-1}$ phosphate buffer ( $\mathrm{pH}$ 6.4) and filtered through $0.3 \mu \mathrm{m}$ Millipore filter immediately before use.

\section{Experimental protocol}

Male Balb/c mice, 26-31 g and 5-7 weeks of age, were maintained at room temperature and allowed free access to food and water. The mice were injected intraperitoneally with ambroxol $\left(70 \mathrm{mg} \cdot \mathrm{kg}^{-1}\right), \mathrm{N}$-acetylcysteine $\left(27.6 \mathrm{mg} \cdot \mathrm{kg}^{-1}\right)$, methionine $\left(25.2 \mathrm{mg} \cdot \mathrm{kg}^{-1}\right)$, or $1 \mathrm{ml}$ buffer alone, once a day for three consecutive days. The molar doses of all drugs were equal $\left(0.169 \mathrm{mmol} \cdot \mathrm{kg}^{-1}\right.$ of body weight). The animals were sacrificed by vertebral dislocation, $3 \mathrm{~h}$ after the last intraperitoneal injection. The thoracic cavity was opened and lungs, heart and liver were excised. Organs were immediately washed with ice-cold phosphate-buffered saline (PBS) ( $\mathrm{pH} \mathrm{7.4)} \mathrm{and}$ then homogenized (125 mg of wet organ in $1 \mathrm{ml}$ PBS). The organ homogenates were stored at $-80^{\circ} \mathrm{C}$ under nitrogen (for not more than for 7 days) until thermal or chemical induction of lipid peroxidation was performed.

\section{Induction of lipid peroxidation}

Thermal induction. Each defrosted individual organ homogenate was divided into two parts. One part was incubated at $50^{\circ} \mathrm{C}$, and the second (control) was kept at $0^{\circ} \mathrm{C}$. After $60 \mathrm{~min}$ incubation, the lipid peroxidation was immediately estimated by measurement of CD [16], as described previously [17]. Briefly, $1 \mathrm{ml}$ of organ homogenate was mixed with $7 \mathrm{ml}$ of chloroform-methanol (1:2 vol/vol), shaken for $2 \mathrm{~min}$ and centrifuged $(15,00 \times \mathrm{g}$ for $5 \mathrm{~min}$ ). Five millilitres of the lower (chloroform) layer was mixed with $2 \mathrm{ml}$ of distilled water acidified with $0.1 \mathrm{~N} \mathrm{HCl}$ to $\mathrm{pH} 2.5$. The mixture was again shaken for $2 \mathrm{~min}$ and centrifuged as above. The chloroform layer was aspirated and dried under a flow of nitrogen gas. The residue was reconstituted with $1 \mathrm{ml}$ of heptane, and its absorbance was read against a heptane blank at $233 \mathrm{~nm}$.

Chemical induction. $\mathrm{H}_{2} \mathrm{O}_{2}$ (final concentration $10 \mathrm{mmol} \cdot \mathrm{l}^{-1}$ ) was added to one portion of the organ homogenate. The control portion received the same amount of deionized water. Samples of lung, liver and heart homogenates were incubated at $37^{\circ} \mathrm{C}$ for 20,15 and $20 \mathrm{~min}$, respectively, and the content of $\mathrm{CD}$ was then measured.

\section{Statistical analysis}

Results are expressed as the mean \pm SD value of absorbance readings at $233 \mathrm{~nm} \cdot \mathrm{g}^{-1}$ of wet organ. The individual increments in the content of CD were calculated by subtracting absorbance readings at $233 \mathrm{~nm}$ found for samples incubated at $0^{\circ} \mathrm{C}$ from values obtained at $50^{\circ} \mathrm{C}$ and by subtracting values obtained with deionized water from those observed when $\mathrm{H}_{2} \mathrm{O}_{2}$ was added. This procedure was performed for all organ homogenates from mice injected with buffer, ambroxol, $\mathrm{N}$-acetylcysteine or methionine, and the results were compared by analysis of variance (ANOVA). The differences between results (the mean basal CD content, the mean CD content after treatment with $\mathrm{H}_{2} \mathrm{O}_{2}$ or heat, the mean increment in $\mathrm{CD}$ content) found in organ homogenates from control buffer-injected mice and those obtained for each drugtreated animal group were determined by multivariate analysis of variance (MANOVA). A p-value of less than 0.05 was considered to be significant.

\section{Results}

Heat- and $\mathrm{H}_{2} \mathrm{O}_{2}$-induced generation of $\mathrm{CD}$ in lung, heart and liver homogenates

Preliminary experiments were performed to find optimal conditions of chemical and thermal induction of lipid peroxidation in lung, liver and heart homogenates. The relationship between the increment in the content of $\mathrm{CD}$ and the temperature, time of incubation and the concentration of $\mathrm{H}_{2} \mathrm{O}_{2}$ was analyzed for all organ homogenates. Figure 1 shows the effect of incubation time at both $0^{\circ}$ and $50^{\circ} \mathrm{C}$ on the content of $\mathrm{CD}$ in lung and heart homogenates. After $30 \mathrm{~min}$ incubation, both organ homogenates revealed significant increase in the content of CD compared to the samples incubated at $0^{\circ} \mathrm{C}$.

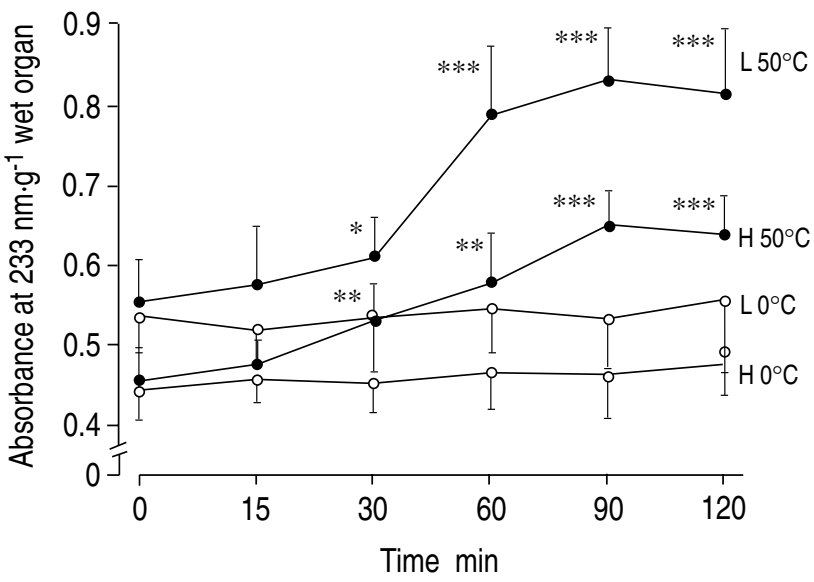

Fig. 1. - Effect of incubation time at $0^{\circ} \mathrm{C}\left(-\mathrm{O}-\right.$ ) and $50^{\circ} \mathrm{C}$ (- $)$ on the content of conjugated dienes (CDs) in lung (L) and heart $(\mathrm{H})$ homogenates. Results, expressed as mean \pm SD of absorbance readings at $233 \mathrm{~nm} \cdot \mathrm{g}^{-1}$ of wet organ, were obtained from seven separate experiments with organs from seven mice. Significance of difference from the equivalent value obtained at $0^{\circ} \mathrm{C}$ : *: $\mathrm{p}<0.05$; **: $\mathrm{p}<0.01$; $* * *: \mathrm{p}<0.001$. 


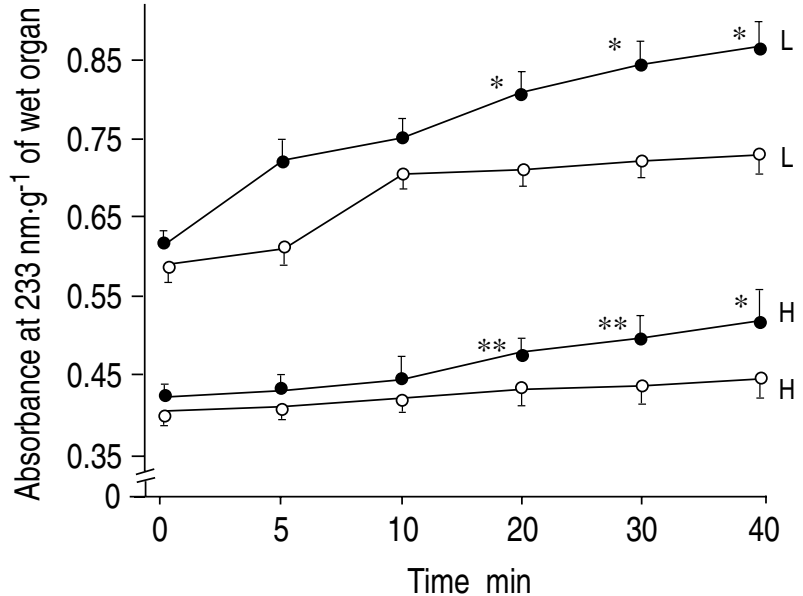

Fig. 2. - Effect of incubation time at $37^{\circ} \mathrm{C}$ on the $\mathrm{H}_{2} \mathrm{O}_{2}$-induced increase in the content of conjugated dienes (CDs) in lung (L) and heart $(\mathrm{H})$ homogenates. Results, expressed as mean \pm SD of absorbance readings at $233 \mathrm{~nm} \cdot \mathrm{g}^{-1}$ wet organ, were obtained from three separate experiments with organs from three mice. Significantly different from the appropriate value obtained in the presence of deionized water: *: $\mathrm{p}<0.05 ; * *: \mathrm{p}<0.01$ - incubation with $10 \mathrm{mmol} \cdot l^{-1}$ $\mathrm{H}_{2} \mathrm{O}_{2}$; - - : control incubation with deionized water.

Similar results were obtained for liver homogenates (data not shown).

Incubation of lung and heart homogenates with 10 mmol $\cdot l^{-1} \mathrm{H}_{2} \mathrm{O}_{2}$ for $\geq 20 \mathrm{~min}$ resulted in a significant increase in the content of $\mathrm{CD}$ (fig. 2). Under these conditions, 2 and $5 \mathrm{mmol} \cdot l^{-1} \mathrm{H}_{2} \mathrm{O}_{2}$ had no significant effect on $\mathrm{CD}$ formation (data not shown). Similar results were obtained for liver homogenates; a significant increase in the content of $\mathrm{CD}$ was already observed after 15 min incubation (data not shown).

Based on these results, 60 min incubation at $50^{\circ} \mathrm{C}$ was used in further experiments for thermal induction of lipid peroxidation in all organ homogenates. 20 min incubation with $10 \mathrm{mmol} \cdot l^{-1} \mathrm{H}_{2} \mathrm{O}_{2}$ was chosen for chemical induction of lipid peroxidation in lung and heart homogenates. Only liver homogenates were incubated for $15 \mathrm{~min}$.

\section{Effect of drug treatment on the basal CD content in lungs and other organs}

The effect of ambroxol, N-acetylcysteine and methionine on the basal CD levels in selected organs in mice was examined in two series of experiments. All drugs injected intraperitoneally for three consecutive days influenced the CD levels in lung, heart and liver homogenates (figs 3 and 4). In the first series of experiments, ambroxol significantly decreased the $\mathrm{CD}$ content in the murine heart and liver, by $1.5(\mathrm{p}<0.01)$ and 1.3 fold $(\mathrm{p}<0.001$ ), respectively, (fig $3 \mathrm{~b}$ and $\mathrm{c}$ ). Lungs from ambroxol-injected mice revealed only a tendency to have lower CD content compared to buffer-treated animals (fig. 3a). However, in the second series of experiments, ambroxol significantly decreased the CD level in all organ homogenates (fig. 4). The absorbance readings at 233 $\mathrm{nm} \cdot \mathrm{g}^{-1}$ of wet organ for lungs, heart and liver from the ambroxol group were, respectively, approximately 1.1 $(p<0.02), 1.2(p<0.01)$ and 1.1 fold $(p<0.01)$ lower than corresponding values observed in buffer-injected mice.
$\mathrm{N}$-acetylcysteine and methionine significantly lowered or tended to decrease the pulmonary and liver basal CD content in both sets of experiments (fig. $3 \mathrm{a}$ and c, and fig. 4a and c). The influence of $\mathrm{N}$-acetylcysteine and methionine on the heart content of $\mathrm{CD}$ was variable being either a decrease (fig. 3b) or increase (fig. 4b), although not always significant.

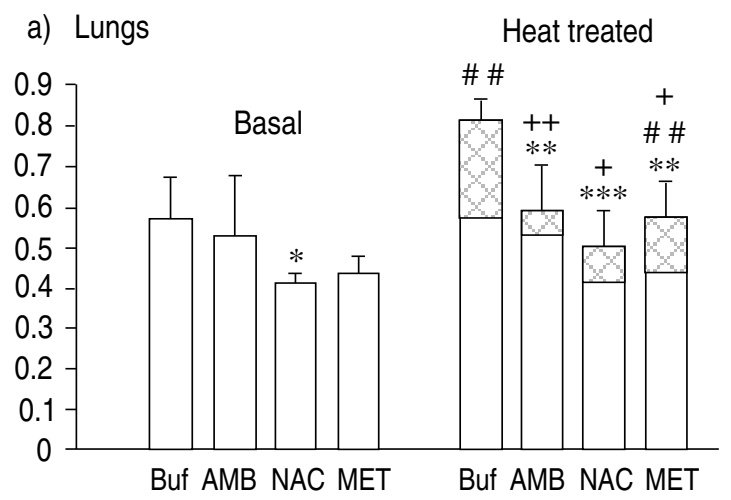

b) Heart

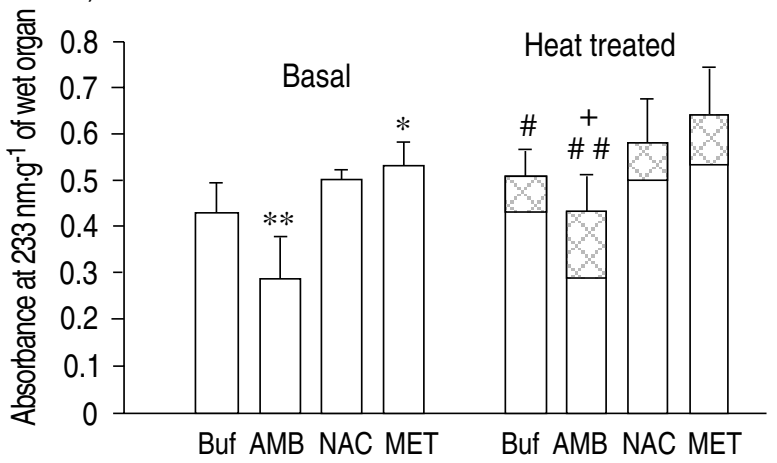

c) Liver

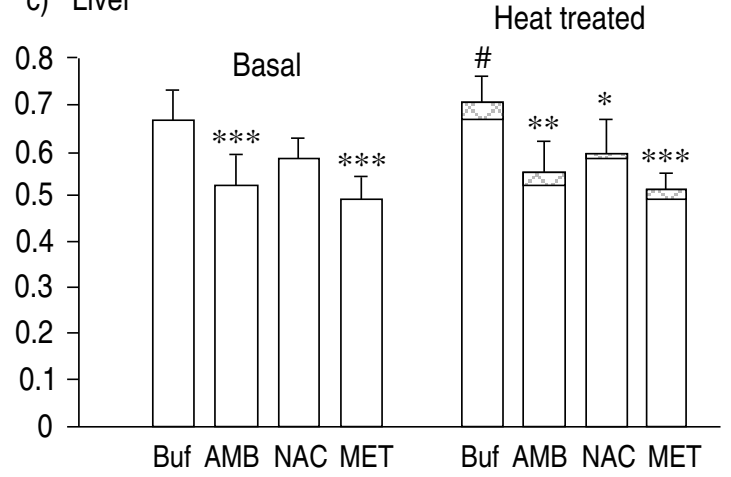

Fig. 3. - Effect of ambroxol (AMB), N-acetylcysteine (NAC) and methionine (MET) on the heat-induced increase in the content of conjugated dienes (CDs) in: a) lungs; b) heart; and c) liver of mice. Mice were injected intraperitoneally with AMB (70 mg. $\left.\mathrm{kg}^{-1}\right)$, NAC (27.6 $\left.\mathrm{mg} \cdot \mathrm{kg}^{-1}\right)$, MET (25.2 $\left.\mathrm{mg} \cdot \mathrm{kg}^{-1}\right)$ or $1 \mathrm{ml}$ buffer (Buf), once a day for three consecutive days. The generation of CDs, expressed as absorbance readings at $233 \mathrm{~nm} \cdot \mathrm{g}^{-1}$ of wet organ, was induced by incubation of the appropriate organ homogenate for $60 \mathrm{~min}$ at $50^{\circ} \mathrm{C}$. Each value represents mean \pm SD of five studies with organs from five mice. $\square$ : indicates increment, above basal, in $C D$ level with heat treatment. *: $\mathrm{p}<0.05 ; * *: \mathrm{p}<0.01 ; * * *: \mathrm{p}<0.001 \mathrm{CD}$ level versus equivalent buffer control. \#: $\mathrm{p}<0.05$; \#\#: $\mathrm{p}<0.01$ significance of increment in the content of CDs;,$+++: \mathrm{p}<0.05,0.01$ increment sig. different from buffer control. 

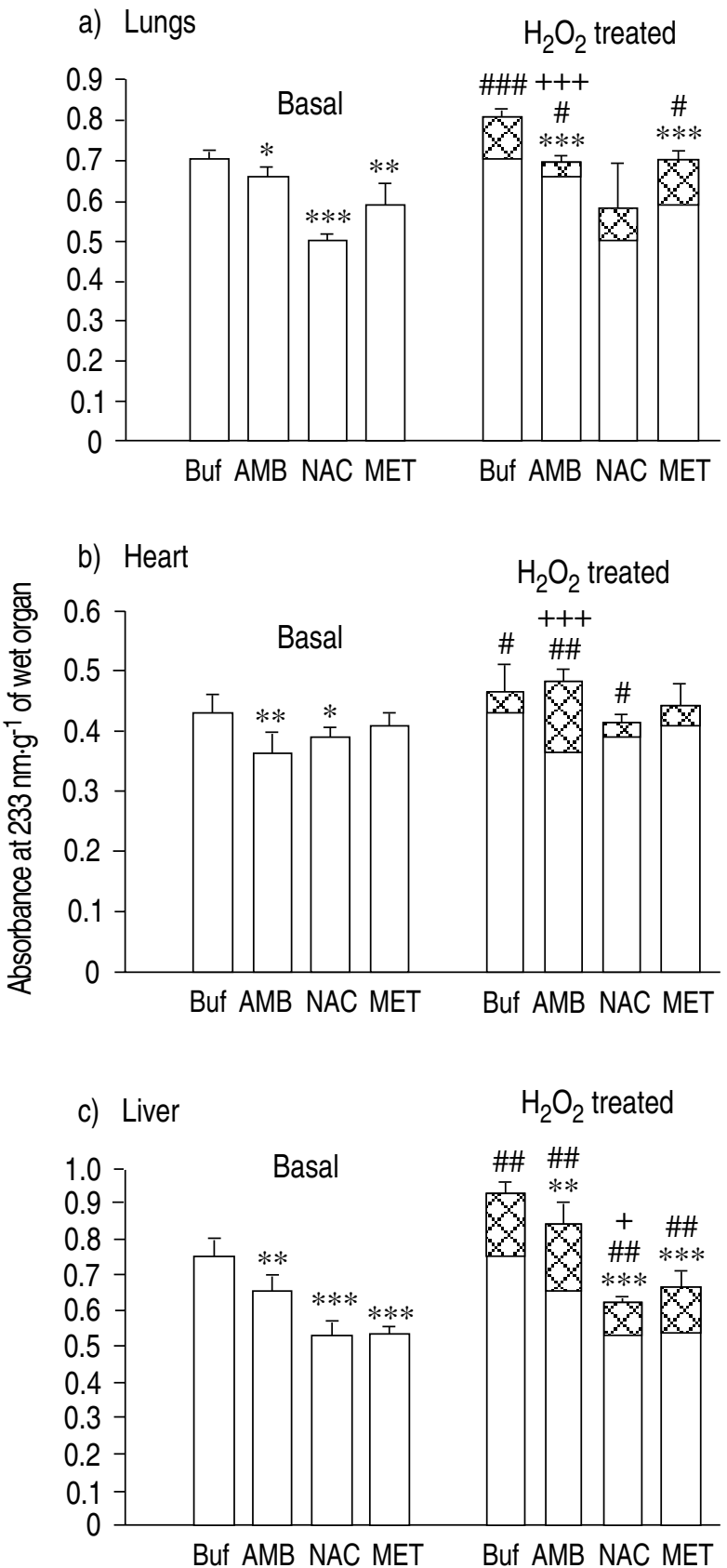

Fig. 4. - Effect of ambroxol (AMB), N-acetylcysteine (NAC) and methionine (MET) on $\mathrm{H}_{2} \mathrm{O}_{2}$-induced increase in the content of conjugated dienes (CDs) in: a) lungs; b) heart; and c) liver of mice. Mice were injected intraperitoneally with AMB $\left(70 \mathrm{mg} \cdot \mathrm{kg}^{-1}\right), \mathrm{NAC}\left(27.6 \mathrm{mg} \cdot \mathrm{kg}^{-1}\right)$, MET (25.2 $\mathrm{mg} \cdot \mathrm{kg}^{-1}$ ) or $1 \mathrm{ml}$ buffer (Buf), once a day for three consecutive days. The generation of CDs, expressed as absorbance readings at 233 $\mathrm{nm} \cdot \mathrm{g}^{-1}$ of wet organ, was induced by incubation of lung, liver and heart homogenates with $10 \mathrm{mmol} \cdot l^{-1} \mathrm{H}_{2} \mathrm{O}_{2}$ for 20,15 and 20 min respectively, at $37^{\circ} \mathrm{C}$. Each value represents mean \pm SD of five studies with organs from five mice. $X$ : indicates increment, above basal, in CD level with $\mathrm{H}_{2} \mathrm{O}_{2}$ treatment. *: $\mathrm{p}<0.05$; **: $\mathrm{p}<0.01$; ***: $\mathrm{p}<0.001 \mathrm{CD}$ level versus equivalent buffer control. \#: $\mathrm{p}<0.05$; \#\#: $\mathrm{p}<0.01$; \#\#\#: $\mathrm{p}<0.001$, significance of increment in the content of CDs.,,$++++++: \mathrm{p}<0.05$, $0.01,0.001$ increment sig. different from buffer control.

Effect of drug treatment on the heat-induced generation of $C D$ in lung, heart and liver homogenates (fig. 3)

Figure 3 shows the effect of intraperitoneal administration of ambroxol, N-acetylcysteine and methionine on the heat-induced lipid peroxidation in organ homogenates. Ambroxol inhibited the thermal generation of $\mathrm{CD}$ in lung homogenates 3.7 fold $(\mathrm{p}<0.01)$ compared to lungs from buffer-treated animals (fig. 3a). The inhibition of the heat-induced CD formation caused by ambroxol $(59.9 \pm 33.1 \%)$ was similar to that with $\mathrm{N}$-acetylcysteine $(61.1 \pm 26.1 \%)$, but 1.4 fold higher than that observed for methionine (42.6 $\pm 24.3 \%)$. Thus, the lungs from ambroxol-, $\mathrm{N}$-acetylcysteine- and methionine-treated mice revealed, respectively, a $1.4(\mathrm{p}<0.01), 1.6(\mathrm{p}<0.001)$ and 1.4 fold $(\mathrm{p}<0.01)$ lower content of $\mathrm{CD}$ after incubation at $50^{\circ} \mathrm{C}$ than lungs from control buffer-injected animals.

All drugs decreased the mean heat-induced increment in CD content of liver homogenates; although not significantly (fig. 3c). None of the drugs inhibited the heatinduced generation of CD in heart homogenates (fig. 3b). Moreover, ambroxol enhanced twofold $(\mathrm{p}<0.05)$ the mean increment in the content of $\mathrm{CD}$ in heart homogenates from $0.071 \pm 0.036$ to $0.140 \pm 0.032$ after the incubation at $50^{\circ} \mathrm{C}$. However, the $\mathrm{CD}$ level in heattreated hearts from ambroxol group did not differ significantly from that found for equivalent hearts harvested from control buffer-injected mice.

Effect of drug treatment on the $\mathrm{H}_{2} \mathrm{O}_{2}$-induced generation of $C D$ in lung, heart and liver homogenates (fig. 4)

Figure 4 summarizes the effect of ambroxol, N-acetylcysteine and methionine on lipid peroxidation in organ homogenates after incubation with $\mathrm{H}_{2} \mathrm{O}_{2}$. The $\mathrm{H}_{2} \mathrm{O}_{2}$ induced generation of $\mathrm{CD}$ in lungs from ambroxoltreated animals was 3.1 fold lower $(p<0.001)$ than that observed in lung homogenates from the control group (fig. 4a). Nevertheless, the mean CD increment was statistically significant, probably due to the low variability of individual results.

Methionine and $\mathrm{N}$-acetylcysteine did not significantly decrease the $\mathrm{H}_{2} \mathrm{O}_{2}$-induced pulmonary increment in the content of CD. However, lungs from methionine-treated mice revealed about a 1.2 fold $(\mathrm{p}<0.001)$ lower content of $\mathrm{CD}$ after incubation with $\mathrm{H}_{2} \mathrm{O}_{2}$ than lungs from control buffer-injected animals. This may be due to reduction of basal pulmonary CD level.

Ambroxol, $\mathrm{N}$-acetylcysteine, and methionine did not reduce $\mathrm{CD} \mathrm{H}_{2} \mathrm{O}_{2}$-induced generation in heart homogenates (fig. 4b). Moreover, heart homogenates from mice treated with ambroxol showed a 3.6 fold higher $(\mathrm{p}<0.001)$ increment in CD than those from control animals. The heart homogenates from each drug-treated animal group did not have a higher CD content, after incubation with $\mathrm{H}_{2} \mathrm{O}_{2}$ than that from control mice.

Only $\mathrm{N}$-acetylcysteine significantly inhibited, by about twofold $(\mathrm{p}<0.05)$, the generation of CD in liver homogenates caused by $\mathrm{H}_{2} \mathrm{O}_{2}$ (fig. 4c). However, all 3 drugs decreased the liver CD level both basal and after incubation with $\mathrm{H}_{2} \mathrm{O}_{2}$.

\section{Discussion}

In our study, we tested ambroxol as an inhibitor of the harmful lipid peroxidation process in murine lungs, and compared its activity with the two antioxidants, 
$\mathrm{N}$-acetylcysteine and methionine. The procedure consisted of the following steps: 1) intraperitoneal administration of the test drug in mice; 2) isolation and preparation of lung homogenates; 3) induction of lipid peroxidation in lung homogenates by heat $50^{\circ} \mathrm{C}$ or $10 \mathrm{mmol} \cdot l^{-1} \mathrm{H}_{2} \mathrm{O}_{2}$; and 4) lung CD content measured. Slight modifications of the incubation time also allowed for evaluation of possible protective effect of the drugs on lipids from other organs, i.e. heart and liver.

We found that ambroxol protected lung lipids from both heat- and $\mathrm{H}_{2} \mathrm{O}_{2}$-induced peroxidation, indicating protection against damage. Methionine and N-acetylcysteine decreased only the heat-induced formation of $\mathrm{CD}$ in lung homogenates, being as effective as ambroxol.

The results are in agreement with our previous experiments showing that ambroxol was equipotent to $\mathrm{N}$ acetylcysteine in inhibition of lipopolysaccharide-induced lung and heart lipids peroxidation in mice [14]. However, in this model, ambroxol could act not only as an antioxidant but also as an inhibitor of phagocyte function and cytokine release $[8,9]$, since it also protected animals from the lipopolysaccharide-induced hypothermic reaction [14]. Our present study clearly indicates that ambroxol can act as an efficient lipid antioxidant. Most of the deleterious effects of $\mathrm{H}_{2} \mathrm{O}_{2}$ on tissues, including lipid peroxidation, depend on its conversion into $\mathrm{OH}$. which is catalysed by iron and copper [18-20]. Recently, we found that ambroxol scavenged $\mathrm{OH} \cdot$ [15], and this may explain its protective effect against $\mathrm{H}_{2} \mathrm{O}_{2}$ on lung lipids. In addition, in vitro ambroxol at concentrations of 25 and $250 \mu \mathrm{M}$ decreased $\mathrm{OH}$-induced peroxidation of linoleic acid by 18 and $66 \%$, respectively [15].

In rats, the lung concentration of ambroxol, measured 3 min after single intravenous treatment of a 6 $\mathrm{mg} \cdot \mathrm{kg}^{-1}$ dose, was about $140 \mu \mathrm{M}$ [21]. Our animals received an 11.6 fold higher dose of drug for three consecutive days. Thus, the pulmonary concentration of ambroxol could reach values corresponding to those able to inhibit linoleic acid peroxidation in vitro. In humans, the plasma concentration of ambroxol determined at 2.5 $\mathrm{h}$ after single oral administration of $90 \mathrm{mg}$ drug was about $0.6 \mu \mathrm{M}$ [22]; however, the pulmonary concentration could be several times higher.

The exact mechanism of the inhibitory effect of ambroxol on the heat-induced lipid peroxidation in lung homogenates remains unknown. Perhaps it can inhibit thermallyinduced hydrogen abstraction from polyunsaturated fatty acids, resulting in the formation of CD. The influence of ambroxol on the reactivity and availability of tissue iron and copper should also be considered. It is possible that ambroxol can chelate these transition metals by the two nitrogens in the molecule, and thus inhibit lipid peroxidation.

Exposure of lung homogenates to heat and $\mathrm{H}_{2} \mathrm{O}_{2}$ increased their CD content. The $\mathrm{CD}$ level in lung homogenates from ambroxol-injected mice was always lower than that from buffer-treated animals. However, only in lungs subjected to action of heat was it accompanied by aboltion of $\mathrm{CD}$ increment. In ambroxol-treated lungs incubated with $\mathrm{H}_{2} \mathrm{O}_{2}$, the CD increment was low but still significant. This may be due to the lower variability of individual results with $\mathrm{H}_{2} \mathrm{O}_{2}$ than those obtained with heat, the more so as ambroxol caused a similar mean decrease (3.7 versus 3.1 fold) of heat- and $\mathrm{H}_{2} \mathrm{O}_{2}$-induced $\mathrm{CD}$ formation, respectively, in lung homogenates. However, the cause may be that of different mechanisms leading to $\mathrm{CD}$ generation by heat and $\mathrm{H}_{2} \mathrm{O}_{2}$. Perhaps the lung lipid peroxidation caused by a relatively high concentration of $\mathrm{H}_{2} \mathrm{O}_{2}\left(10 \mathrm{mmol} \cdot l^{-1}\right)$ is less susceptible to changes of antioxidant activity in separate organs of mice than that induced by heat. Therefore, the individual $\mathrm{H}_{2} \mathrm{O}_{2}$-dependent $\mathrm{CD}$ increments were more reproducible and, although the mean CD increment was low, it was statistically significant.

In earlier work, we found that ambroxol almost completely inhibited the endotoxin-induced generation of CD in both heart and lungs of mice [14]. The heart concentration of ambroxol after a single intravenous injection was threefold lower than that in lungs but twofold higher than that in liver [21]. In addition, the antioxidant defence of heart is lower than that of lungs and liver [23]. Therefore, we additionally evaluated the effect of administration of ambroxol on heat- and $\mathrm{H}_{2} \mathrm{O}_{2}$-induced formation of $\mathrm{CD}$ in heart and liver homogenates. Ambroxol had no influence on lipid peroxidation in liver, but enhanced the increment in $\mathrm{CD}$ content in heart homogenates induced either by $\mathrm{H}_{2} \mathrm{O}_{2}$ or heat. On the other hand, the basal CD content in heart homogenates obtained from ambroxol-treated mice was lower than that observed in control buffer-treated animals. Moreover, the final CD content (after heating and incubation with $\mathrm{H}_{2} \mathrm{O}_{2}$ ) in heart homogenates from ambroxol-injected mice was similar to the basal value found in the control group. Therefore, it is difficult to conclude whether ambroxol revealed the pro-oxidant effect in heart homogenates and this question requires further studies. Perhaps, the low activity of antioxidant enzymes, such as superoxide dismutase and glutathione peroxidase, in murine heart [23], and myoglobin-derived iron may be partly responsible for these observations.

As mentioned above, ambroxol decreased the basal CD content in all organ homogenates, and both $\mathrm{N}$-acetylcysteine and methionine lowered the lung and liver CD level, but proved variable on heart $\mathrm{CD}$ level. It cannot be excluded that this may have a further influence on $\mathrm{CD}$ formation in organ homogenates following heat or $\mathrm{H}_{2} \mathrm{O}_{2}$ exposure. It is possible that the lower basal tissue lipid peroxidation may allow a higher increment in CD content under the conditions of our experiments, because more polyunsaturated fatty acids are available for peroxidation. Thus, to some extent, it can mask the protective effect of antioxidant. Nevertheless, ambroxol significantly decreased the heat- and $\mathrm{H}_{2} \mathrm{O}_{2}$-induced CD generation in lung homogenates. On the other hand, it seems quite clear that in vivo administration of an antioxidant can simultaneously decrease both the basal and the provoked lipid peroxidation.

Unfortunately, in many studies concerning the protection of lung lipids from peroxidative damage, the influence of antioxidants and free radical scavengers on the basal pulmonary level of lipid peroxidation products was not 
determined [24-27]. However, our results are supported by the observations of HeRshKo et al. [28], who found that $\alpha$-tocopherol decreased the basal level of malondialdehyde (a lipid peroxidation product) in myocardial cell cultures, and also inhibited iron-induced lipid peroxidation in these cells.

Our study indicates that ambroxol can act as a sufficient lung lipid antioxidant. This may be of value, in view of the fact that ambroxol is often used in adjuvant treatment of chronic bronchitis and pulmonary emphysema, which are (among others) characterized by oxidantantioxidant imbalance in the lower airways [29, 30].

Acknowledgements: The authors would like to thank W. Trautner from Boehringer Ingelheim (Vienna) and M. Migdal from Boehringer Ingelheim (Warsaw) for their support.

\section{References}

1. Smith LL. The response of the lung to foreign compounds that produce free radicals. Ann Rev Physiol 1986; 48: 681-692.

2. Pryor WA. Oxy-radicals and related species: their formation, lifetimes and reactions. Ann Rev Physiol 1986; 48: 657-667.

3. Cerutti P, Kapanci Y. Effects of metabolite VIII of bromhexine ( $\mathrm{Na} \mathrm{872)}$ on type II epithelium of the lung. An experimental and morphological study with reference to surfactant secretion. Respiration 1979; 37 : 241-251.

4. Winsel K. Antioxidative und entzündungshemmende Eigenschaften von Ambroxol. Pneumologie 1992; 46: 461-475.

5. Rozniecki J, Nowak D. Effect of ambroxol on the chloramine $\mathrm{T}$-induced decrease of serum elastase inhibitory capacity in vitro. Lung \& Respiration 1987; 4: $14-15$.

6. Stockley RA, Shaw J, Burnett D. Effect of ambroxol on neutrophil chemotaxis in vitro. Agents Actions 1988; 24: 292-296.

7. Rozniecki J, Nowak D. Ambroxol inhibits spontaneous migration of human neutrophils. Clin Exp Allergol 1990; 20 (Suppl. 1): 27.

8. Winsel K, Becher G. Effects of ambroxol on chemiluminescence of phagocytic cells and Na-arachidonateinduced bronchoconstriction in guinea-pigs. Eur Respir J 1992; 5 (Suppl. 15): 289.

9. Bianchi M, Mantovani A, Erroi A, Dinarello CA, Ghezzi P. Ambroxol inhibits interleukin-1 and tumor necrosis factor production in human mononuclear cells. Agents Action 1990; 31: 275-279.

10. Luisetti M, Peona V, Salmona M, et al. Ambroxol and pulmonary toxicity induced by antineoplastic drugs. Int J Clin Pharmacol Res 1986; 6: 129-136.

11. Donnini M, Luisetti M, Diomede L, et al. Ambroxol reduces paraquat toxicity in the rat. In: Wichert $\mathrm{P}$, von Muller B, eds. Basic Research on Lung Surfactant. Progress in Respiratory Research. Karger Basel, 1990; 25: pp. 329-332.

12. Nowak D, Pietras T, Antczak A, Krol M. Inhibition of endotoxin-induced lipid peroxidation by ambroxol in mice. Lung \& Respiration 1993; 10: 14-15.
13. Bernard GR. N-acetylcysteine in experimental and clinical acute lung injury. Am J Med 1991; 91 (Suppl. 3C): 54-59.

14. Nowak D, Pietras T, Antczak A, Krol M, Piasecka G. Ambroxol inhibits endotoxin-induced lipid peroxidation in mice. Pol J Pharmacol 1993; 45: 317-322.

15. Nowak D, Antczak A, Krol M, Bialasiewicz P, Pietras T. Antioxidant properties of ambroxol. Free Rad Biol Med 1994; 16: 517-522.

16. Buege JA, Aust SD. Microsonal lipid peroxidation. In: Fleischer S, Packer L, eds. Methods in Enzymology. New York, Academic Press, 1978; 52: pp. 303-310.

17. Nowak D, Pietras T, Antczak A, Krol M, Piasecka G. Effect of bacterial lipopolysaccharide on the content of lipid peroxidation products in lungs and other organs of mice. Anton Leeuwenhoek Int J Gen M 1993; 63: $77-83$.

18. Mello Filho AC, Hoffmann ME, Meneghini R. Cell killing and DNA damage by hydrogen peroxide are mediated by intracellular iron. Biochem J 1984; 218: 273-275.

19. Imlay JA, Chin SM, Linn S. Toxic DNA damage by hydrogen peroxide through the Fenton reaction in vivo and in vitro. Science 1988; 240: 640-642.

20. Rowley DA, Halliwell B. Superoxide-dependent and ascorbate-dependent formation of hydroxyl radicals in the presence of copper salts: a physiologically significant reaction? Arch Biochem Biophys 1983; 225: 279284.

21. Greischel A, Schumacher K. Gewebespiegel und Metabolitenmuster nach i.v. Gabe von $\left[{ }^{14} \mathrm{C}\right] \mathrm{N}-\mathrm{A} 872 \mathrm{Cl}$ in verschiedenen Dosierungen als Bolus bzw. Infusion bei der Ratte. Interner Bericht Dr K. Thomae GmbH, Biberach an der Riss 1986; 1: 9 (Doc Nr.: U86-0780).

22. Nobilis M, Pastera J, Svoboda D, Kvetina J. Highperformance liquid chromatographic determination of ambroxol in human plasma. J Chromatogr 1992; 581: 251-255.

23. Doroshow IH, Locker GY, Myers CE. Enzymatic defenses of the mouse heart against reactive oxygen metabolites. J Clin Invest 1980; 65: 128-135.

24. Kennedy TP, Rao NV, Noah W, et al. Ibuprofen prevents oxidant lung injury and in vitro lipid peroxidation by chelating iron. J Clin Invest 1990; 86: 1565-1573.

25. Al-Mehdi AB, Dodia C, Jain MK, Fisher AB. A phospholipase $\mathrm{A}_{2}$ inhibitor decreases generation of thiobarbituric acid reactive substances during lung ischemiareperfusion. Biochem Biophys Acta 1993; 1167: 56-62.

26. Ward PA, Till GO, Hatherill JR, Annesley TM, Kunkel RG. Systemic complement activation, lung injury and products of lipid peroxidation. J Clin Invest 1985; 76: 517-527.

27. Till GO, Hatherill JR, Tourtellotte WW, Lutz MJ, Ward PA. Lipid peroxidation and acute lung injury after thermal trauma to skin. Evidence of a role for hydroxyl radical. Am J Pathol 1985; 119: 376-384.

28. Hershko C, Link G, Pinson A. Modification of iron uptake and lipid peroxidation by hypoxia, ascorbic acid, and $\alpha$-tocopherol in iron-loaded rat myocardial cell cultures. J Lab Clin Med 1987; 110: 355-361.

29. Riley DJ, Kerr JS. Oxidant injury of the extracellular matrix: potential role in the pathogenesis of pulmonary emphysema. Lung 1985; 163: 1-13.

30. Stockley RA. Alpha ${ }_{1}$-antitrypsin and the pathogenesis of emphysema. Lung 1987; 165: 61-77. 